\title{
KRONIK
}

\section{Soğuk Savaş Neden Yeniden Sona Erdi?}

Yrd. Doç. Dr. Erel Tellal, A.Ü. Siyasal Bilgiler Fakültesi

Rusya Federasyonu Devlet Başkan Vladimir Putin, 29 Mayısta Moskova'da başlayan dokuzuncu Rusya Federasyonu-AB Doruğu'nu açış konuşmasına şu sözlerle başladi: "Soğuk Savaş'ın cenaze töreni nihayet sona erdi". Başkan Bush da Mayıs sonundaki zirvenin ardından yaptığı basın toplantısında "Soğuk Savaş dönemi sona erdi. Bu savaşın sonuçlarını sildik" şeklinde açılama yapmıştı. Peki, neydi Soğuk Savaş ve yaklaşık on yıl önce SSCB'nin dağılmasıyla (ya da bir iki yil önce kendisini simgeleyen Berlin Duvarı'nın yıkılmasıly) sona ermemiş miydi? Eğer öyle ise, 2002'de Soğuk Savaş neden yeniden sona erdi?

Öncelikle sona erdiği söylenenin ne olduğuna kısaca değinmek açılayıcı olacaktır. Soğuk Savaş çok değişik biçimlerde tanımlanmış ve dönemlere ayrilmıştır. En genel tanımıyla Soğuk Savaş, "tarafların birbirlerine karşı silaha başvurmaktan çekindikleri çatı̧̧ma" anlamına gelmektedir. Ilk kez 14. yüzyılda kullanılmasına karşın, 20. yüzyılda, 1945'te Hitler karşıtı bağlaşmanın çözülmesinden sonra ABD ile SSCB arasındaki "çatışma"yı anlatır: Soğuk Savaş, "Ikinci Dünya Savaşı'nun ardından başlayan, birbiriyle yarı̧ halindeki iki süper gücün ve bunların başını çektiği iki kutuplu uluslararası sistemin geçerli olduğu süreçtir". Fred Halliday'e göre Soğuk Savaş, idcolojik farklılıklar çerçevesinde yaşanan sistemler arası bir çatı̧̧madır ve kaçınılmazdır. Her iki sistem de (Kapitalizm ve Bolşevizm) dünya ölçeklidir. Ideoloji, 20. yüzyılda kullanıldiğı anlamda Soğuk Savaş'ta çok önemli yer tutar. Ancak, tek belirleyici değildir. Soğuk Savaş'a yalnuzca ideolojik açıdan yaklaşanlar, ne onun neden 1917'de değil de 1945/47'de başladığını, ne de neden Çin'e karşı değil de SSCB'ye karşı yürütüldüğünü açıklayabilirler. Buradan yola çıkarak, Soğuk Savaş'ın aslında "iki sistem arasındaki bir çatışma olmadı̆̆ı, tam tersi her sistemin bir diğerini gereksindiği" yorumunu yapanlar da vardır: "Her ikisi de yüksek düzeyde askeri harcamalara ve sürekli dış tehdide zorunludur. Her birinin varlığ diğeri için meşruiyet sağlamaktadır". Nasıl tanumlanursa tanumlansın, Soğuk Savaş'a "soğuk" niteliğini veren, yani tarafların birbirlerine karşı silaha başvurmaktan çekinmelerine yol açan nükleer silahlardır. Gelişen teknolojiyle birlikte dünyayı yokedebilecek güce erişen bu silahların kullanılması olasılığı tarafları caydırmıs ve görüşmelere zorlamıştır.

Soğuk Savaş'a iliş̧kin bu kısa değerlendirmenin ardından 11 Eylül sonrasında ABD ile Rusya Federasyonu arasında yaşanan yakınlaşmayı incelemeye geçebiliriz. Putin, 11 Eylül saldırısının hemen ardından Başkan Bush'u arayarak 
terörizme karşı ABD'nin yanında olduğunu açklamıştı. Ardından, Afganistan operasyonunda işbirliği yapmasının yanı sıra ABD'nin Kafkaslar ve Orta Asya'ya askeri birlik göndermesine göz yumdu. Bu, Rusya Federasyonu'nun 1990'larda izlediği "yakın çevre" politikasını gözden geçirdiği anlamına geliyordu. Rusya Federasyonu'nun ABD'yle (buna daha esnek biçimde Batı yada Kuzey de denilebilir) işbirliği bununla da kalmadı. Aralık ayında ABD'nin ulusal füze savunma sisteminin (NMD) Rusya Federasyonu'nun güvenliğini tehdit etmeyeceğini açıkladı. NMD Soğuk Savaş döneminde kurulan nükleer dengenin bel kemiği olan füzesavar anlaşmasının ( $A B M)$ sona ermesi anlamına geliyordu. Soğuk Savaş'ın sona erdiğini ilan edenler, aslında, Soğuk Savaş dönemindeki bu nükleer dengenin sona erdiğini anlatmak istediler.

Rusya Federasyonu, 2002'nin ilk yarısında "olumlu yaklaşım"ını sürdürdü ve bunun kazanumlanı da elde etmeye başladı. Ilkin, Mayıs ayında Bush'un Moskova ziyaretinde nükleer silah başlıklarının azaltılmasına ilişkin bir anlaşma imzalandı. Anlaşma uyarınca savaş başlıkları on yıl içerisinde 6000 'den 1700-2200 aralığına çekilecektir. Nükleer silah başlıklarının azaltılması, içinde bulunduğu ekonomik kısitllıklar nedeniyle bunların bakımında zorlanan Rusya Federasyonu'nu rahatlatacaktır. Başkan Bush'un Avrupa turunun bir ayağı olan Moskova gezisi yalnuzca bu anlaşmayla kalmadı. Fransa'yla anlaşmazlıkların çözemeyen, Almanya'da Kennedy'nin gezisi anımsatılarak "sen Berlin'li değilsin!" pankartlarıyla karşılanan, Uluslararası Ceza Mahkemesi'nden çelik dışalımına koyulan kısıtlamalara pek çok konuda $A B$ ile anlaşamayan Bush, Moskova'da çok sıcak karşılandı. Terörizme karşı işbirliği ve Avrasya'da ortak eylem planı kabul edildi. Böylece bir yandan $A B D$ ile $A B$ arasındaki anlaşmazlıklar su yüzüne çıkarken, Putin iktidarında toparlanmaya başlayan Rusya Federasyonu bu anlaşmazlıkları kendi çıkarları doğrultusunda ustaca kullanmaya başladı.

Ikinci olarak, yine Mayis sonunda Italya'da Practica di Mare üssünde NATO-Rusya Konseyi kuruldu. Rusya Federasyonu'nun NATO ile ilişkileri SSCB dönemine dayaniyordu. NATO ile Rusya Federasyonu arasinda Kuzey Atlantik Işbirliği Konseyi çerçevesinde 1991'de başlayan görüşmeler, 22 Haziran 1994 tarihinde "Barı̧ Için Ortaklık" (BIO) çerçevesinde imzalanan "Kapsamlı ve Güçlendirilmiş Diyalog ve Işbirliği" belgesiyle sonuçlanmışt. Rusya Federasyonu ile NATO arasında yürütülen görüsmeler "16+1" olarak anıldı ve 1995 'te bir NATO temsilcisi Moskova'ya tayin edildi. ABD önderliğinde NATO birliklerinin Yugoslavya'yı bombalaması sırasında yaşanan anlaşmazlıklar bir yana birakılırsa Rusya Federasyonu ve NATO IFOR (Uygulama Gücü) ve SFOR'da (Istikrar Gücü) işbirliği yaptılar. 27 Mayıs 1997'de "Karşlıkh lliş̧iler, Işbirliği ve Güvenliğe tlişkin Kurucu Senet" imzalandı. Kurucu Senet'in ikinci bölümü NATO-Rusya Daimi Ortak Konseyi'ni (PJC) kurdu. Ama, PJC NATO'nun karar alma birimi Kuzey Atlantik Konseyi'nden tamamen ayrı idi. 
1999 'da Çek Cumhuriyeti, Polonya ve Macaristan'ın üyeliğe kabul edilmelerinin ardından Rusya Federasyonu ile sürdürülen ilişkiler "19+1" olarak anılmaya başlandı. 2002 sonbaharında Prag'da Estonya, Letonya, Litvanya, Slovenya, Romanya, Bulgaristan, Slovakya NATO'ya katlacaklar. Böylece eski Doğu Bloğu ülkelerinden sonra eski SSCB ülkeleri de NATO'ya katılmış olacaklar. Bu da Soğuk Savaş'in sona erdiğinin başka bir göstergesi olacak.

1990'larda ilişkilerinin temellerini atan Rusya Federasyonu ve NATO, 28 Mays 2002'de bir bildirge imzaladılar: "NATO-Rusya Iliskileri: Yeni Nitelik". Bu bildirge NATO-Rusya Konseyi'ni kurmaktadrr. Konsey, Kurucu Senet'le kurulan NATO-Rusya Daimi Ortak Konseyi'nin yerini allyor. Konsey'in kurulması NATO'nun ortak savunmaya dayalı varolan siyasal ve askeri sorumluluklann etkilemeyecek. Başka bir deyişle, NATO'ya askeri bağlaşma niteliği veren ve üyelerden biri saldırıya uğradığında, diğer üyelerin BM 51. maddesine dayanarak "meşru savunma" hakların kullanacakların öngören NATO'nun ünlü 5. maddesi Rusya Federasyonu'na uygulanmayacak. Yine, Bildirge uyarnnca Konseyde alınan kararlarda Rusya Federasyonu diğer NATO üyeleriyle eşit söz ve oy hakkına sahip olacak. Konsey'de kararların oydaşmayla alınması öngörülüyor ve Rusya Federasyonu'na veto hakkı tanınmıyor.

Üçüncüsü, Roma zirvesinin ardından Moskova'da Rusya Federasyonu-AB doruğu dokuzuncu kez toplandı. Bu da Rusya Federasyonu'nun ABD'nin yan sıra $A B$ ile de ilişkilerini gözden geçirdiği bir platform oldu. Toplantıda AB'nin Baltık ülkelerine genişlemesi durumunda $A B$ toprakları içerisinde bir Rus toprağı (eksklav) olarak kalacak Kaliningrad'in konumu ana gündem maddesiydi. Olası bir genişlemede Kaliningrad'ta yaşayan Rus vatandaşlarının dolaşım haklan ve ana devletle iletişimleri çözümü bekleyen bir sorun olarak duruyor. Dorukta ayrica AB'nin Rusya Federasyonu'nu pazar ekonomisi olarak tanıması, bilimsel araştırmalar, uzay çalı̧̧maları gündeme geldi. AB, Rusya Federasyonu'na "pazar ekonomisinin şartların tam olarak yerine getiren ülke" statüsünü vereceğini açıkladı.

Dördüncüsü, bu iki zirvenin ardından yine Haziran başında ABD Ticaret Bakanlığı AB'yi beklemeden Rusya Federasyonu'na "pazar ekonomisi" statüsü tanıdı. Bu, Rusya Federasyonu'nun Dünya Ticaret Örgütü'ne (DTÖ) girmesinin önünü açacak ve böylece kapitalist ekonomik sisteme eklemlenmesini sağlayacak çok önemli bir gelişmedir. Bir yandan Rusya Federasyonu'nun ABD ile ticaret hacmini arttrmasın sağlarken, öte yandan ABD'den bu ülkeye sermaye akışın hızlandıracaktır.

Son olarak, Kananaskis (Kanada) Zirvesi'nde Rusya Federasyonu 8'lere katıldı. Rusya Federasyonu'nun 8'ler Grubu içindeki yeri de süreç içerisinde pekişti. 7'ler Zirveleri sonrasinda düzenlenen ortak toplantlar SSCB dönemine (1991) dayanyordu. Rusya Federasyonu 1994'te Napoli zirvesinde siyasi toplantlara 


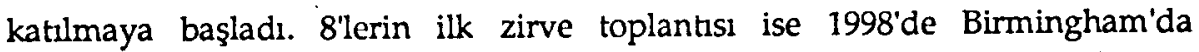
gerçekleşti. 8'ler Grubu Rusya Federasyonu'nun borç ve kredilerinin düzenlendiği bir platform olageldi. 27-28 Haziran 2002'de Kanada'da toplanan 8'ler zirvesinde üç temel amaç belirlendi: Terörizme karşı savaş, küresel ekonomik gelişmeyi sağlama, özellikle Afrika'da ekonomik gelişme için işbirliği. Rusya Federasyonu 2006'da 8'lerin başkanlı̆̆ın üstlenecek ve zirveye evsahipliği yapacak. ${ }^{1}$ Bu karara gerekşe olarak, "Rusya Federasyonu'nun küresel sorunların çözümünde oynadığı anlamlı katkı ile Putin önderliğinde başlattığ 1 ekonomik ve demokratik dönüşümü" gösterildi. Zirvede ayrıca Rusya Federasyonu'nun kitlesel imha silahlarının temizlenmesi için gelecek 10 yll içinde 20 milyar dolar özgülenmesi kararı da çıtı.

Rusya Federasyonu'nun 8'lere kathlması ilginç bir gelişmedir. Zira, bu gruba üye olmak için aranan pazar koşulları altında gelişmiş ekonomiye sahip olma, insan haklanna saygı ve demokratik siyasal sistem gibi ölçütleri Rusya Federasyonu'nun ne denli yerine getirdiği tartışmalıdır. Buna karşın küresel düzeyde sorunlara çözüm arama iddiasındaki 7'ler, aralanna Rusya Federasyonu'nu da almışlardır. Rusya Federasyonu yeniden kurulmaya çalışılan uluslararası sistemin dışında buraklamayacak denli önemli bir devlettir. BM Güvenlik Konseyi'ndeki sürekli üyeliği ve veto hakkının yanı sıra sahip olduğu nükleer silahlar Rusya Federasyonu'nu sistem açısından vazgeçilmez klar. Üstelik, sorun olarak saptanan pek çok konu (terörizm, uyuşturucu ticareti, nükleer silahların yayılması vb.) Rusya Federasyonu'yla doğrudan ilintilidir ve onsuz çözülemez. SSCB'nin yıkılmasının ardından yaşanan ekonomik çöküntü ülkeyi dünyanun en önemli mafya merkezlerinden bir haline getirmiştir.

Rusya Federasyonu'nun NATO'yla özel ilişkiler kurması ve 8'lere üyeliği Soğuk Savaş ertesinde yeniden kurulan uluslararası sisteme ilişkin ipuçları vermekte ve yeni oluşum sorgulanmaktadır. Örneğin, Wallerstein soruyor: NATO kime karşı ? Die Welt yazarı Nikolaus Blome öneriyor: Çin de katılsın, adı 9'lar Grubu olsun. Vaclav Havel ise uyarıyor: Kuzeyin Güneye (zenginin fakire) karş1 birleştiği izlenimini vermekten kaçınmalıyız. Günümüzde sermayenin özgür dolaşımı biçiminde gelişen küreselleşme yeni bir sömürge ve kolonileşme harekatı biçiminde ortaya çkmaktadır. IMF, DB, DTÖ, 8'ler Grubu, genişleyen NATO gibi ekonomik, siyasi ve askeri örgütlenmeler eliyle yürütülen sürec, kredi-borç döngüsüyle bunu yürütmcktedir. Rusya Federasyonu da bu sürec içerisinde kendisine yer bulmaya çalışmaktadır.

2002 'nin ilk yarısında tanuk olunan bu gelişmeler açıkça göstermiştir ki, ABD ile SSCB arasında 20. yüzyılın ikinci yansında yaşanan Soğuk Savaş sona ermiştir. Burada alt çizilmesi gereken nokta, sona erenin ABD ile SSCB (ve onun ardılı

1 Zirveler sırasıyla Birleşik Devletler (2003), Fransa (2004), Birleşik Krallık (2005), Rusya Federasyonu (2006), Almanya (2007), Japonya (2008), Italya (2009) ve Kanada'da (2010) toplancak. 
sufatyyla Rusya Federasyonu) arasındaki Soğuk Savaş olduğudur. Bu süreç 1989'da Berlin Duvarı'nın yıkılmasıyla başlamış, 1991 sonunda SSCB'nin yikılmasıyla sürmüş, 11 Eylül'den sonra Rusya Federasyonu'nun NATO ile özel ilişkiler kurması ve 8'ler Grubu'na katılmasıyla yeni bir aşamaya ulaşmıştır. Büyük bir olasılıkla Prag'da NATO'ya yeni katılımların gerçekleşmesinin ardından Soğuk Savaş'in sona erdiği bir kez daha ilan edilecektir. Fakat, nükleer silahların yok edici etkisiyle ortaya çıkan Soğuk Savaş kavramı, bu silahlar bütünüyle ortadan kaldırlmaksızın uluslararası siyaset sahnesinden inmeyecektir. Belki sahne değişecek, belki aktörler değişecek ama perde kapanmayacaktur. Nükleer silahlar, onlara sahip olanlar tarafindan o ya da bu yolla diğerlerine karşı bir tehdit olarak kullanıldığı sürece Soğuk Savaş kavramıyla karşılaşacağız. Hele, günümüzde $\mathrm{ABD}$ Soğuk Savaş döneminde inşa edilen nükleer dengeyi yıkma pahasına bir "ulusal füze kalkanı" kurmaya çalışırken Soğuk Savaş'ın bittiğinden söz etmek anlamlı olmayacaktır. 